GHÂNCARAN: JURNAL PENDIDIKAN
BAHASA DAN SASTRA INDONESIA
E-ISSN : XXXX-XXXX ; P-ISSN: XXXX-XXXX
E

\title{
Nilai-Nilai Pendidikan dalam Novel Ki Hadjar Sebuah Memoar Karya Haidar Musyafa: Perspektif Diane Tillman
}

\author{
Imam S. Arifin dan Iswah Adriana \\ Tadris Bahasa Indonesia, IAIN Madura \\ Alamat surel: imameror@gmail.com
}

\begin{tabular}{l}
\hline \hline \\
\hline Keywords: \\
Educational \\
Value \\
Novel \\
Ki Hadjar
\end{tabular}

\begin{abstract}
Novel Ki Hadjar Sebuah Memoar is a novel written by Haidar Musyafa, this novel tells the story of life of the father of Indonesia education Ki Hadjar Dewantara. The struggle of Ki Hadjar and Indonesia Youth is told in this novel from the formation of Boedi Oetomo. Taman Siswa to the independence of Indonesia from colonist. This novel contain many education values that are beneficial to the reader. Based on this, then there are problems that are the main study in this research : how the form of educational values in ki hadjar's novel a memoar by Haidar Musyafa Diane Tillman perspective. This research used the decsriptive approach method and type of this research is library research. Data source obtained throught Ki Hadjar's novel memoar. Data collection techniques used by researcher are by reading books related to literature and educational values. In analyzing the data in the novel ki hadjar an memoar by Haidar Musyafa. The researcher conducted several stages, namely: identifying forms of educational values, classifying the types of educational values and describing educational values in the ki hadjar an memoar novel by haidar
\end{abstract} musyafa.

\section{Abstrak:}

Kata Kunci:

Nilai pendidikan

Novel

Ki Hadjar
Novel Nilai-Nilai Pendidikan dalam Novel Ki Hadjar Sebuah Memoar merupakan novel yang ditulis oleh Haidar Musyafa. Novel ini mengisahkan tentang kehidupan bapak pendidikan Indonesia Ki Hadjar Dewantara. Perjuangan Ki Hadjar dan pemuda Indonesia diceritakan dalam novel ini mulai dari terbentuknya Boedi Oetomo, tamansiswa hingga kemerdekaan Indonesia dari penjajah. Penelitian ini bertujuan untuk mengetahui bentuk nilai-nilai pendidikan dalam novel Ki Hadjar Sebuah Memoar karya Haidar Musyafa Perspektif Diane Tillman. Penelitian ini menggunakan metode pendekatan deskriptif dan jenis penelitian kepustakaan. Sumber data yang diperoleh melalui novel Ki Hadjar Sebuah Memoar. Teknik pengumpulan data yang digunakan oleh peneliti yaitu dengan membaca dan mencatat. Dalam menganalisis data pada novel Ki Hadjar Sebuah Memoar karya Haidar Musyafa, peneliti melakukan beberapa tahapan, yaitu: mengidentifikasi, mengklasifikasikan, mendeskripsikan nilai-nilai pendidikan dalam novel Ki Hadjar Sebuah Memoar karya Haidar Musyafa, sedangkan pengecekan keabsahan data dilakukan melalui ketekunan/keajengan pengamatan. Penelitian ini menunjukkan bahwa novel ini kaya akan nilai pendidikan. 


\section{PENDAHULUAN}

Dalam penciptaan karya sastra, pengarang merekam gejala-gejala sosial yang terjadi dalam masyarakat yang menjadi inspirasi lahirnya sebuah karya sastra. Segala fenomena dan permasalahan dalam masyarakat dijadikan objek dalam dunia sastra. Karya sastra dapat dipandang sebagai gejala sosial. la menceritakan cermin kehidupan. Hal itu berarti bahwa sastra menggambarkan kenyataan yang terjadi dalam kehidupan masyarakat. Jadi, lingkungan sosial yang terdapat di sekeliling pengarang sangat mempengaruhi lahirnya sebuah karya sastra. (Luxemburg, 1986: 23)

Salah satu karya sastra yang sangat populer terutama dikalangan anak muda adalah novel. Novel merupakan salah satu karya sastra berbentuk prosa. Sebagai karya sastra novel diciptakan oleh pengarangnya untuk dapat memberikan kenikmatan, kesenangan dan manfaat bagi pembacanya. Pada umumnya novel menceritakan peristiwa-peristiwa yang mengandung nlai-nilai. Nilai-nilai dalam novel merupakan pesan yang ingin disampaikan pengarang kepada pembacanya, baik itu secara tersurat atau tersirat (Wellek \& Werren, 2016:296).

Novel bisa dikatakan sebagai karya sastra yang baik apabila didalamnya mengandung nilai-nilai yang mendidik. Melalui pemahaman dan penikmatan terhadap novel pembaca bisa menangkap nilai-nilai pendidikan yang pengarang tuangkan dalam novel. Oleh karena itu, banyak pengarang novel yang menjadikan karyanya sebagai media untuk menyampaikan nilai-nilai pendidikan. Pendidikan adalah segala usaha orang dewasa dalam pergaulan dengan anak-anak untuk memimpin perkembangan jasmani dan rohaninya ke arah kedewasaan. Rumusan tentang pendidikan, lebih jauh termuat dalam UU. No. 20 Tahun 2003, bahwa pendidikan Indonesia bertujuan agar masyarakat Indonesia mempunyai pengendalian diri, kepribadian, kecerdasa, akhlak mulia, serta keterampilan yang diperlukan dirinya, masyarakat, bangsa dan negara. Artinya, arah dari proses pendidikan nasional mencakup berbagai aspek kehidupan diri manusia dan masyarakat untuk survive dalam kehidupan berbangsa dan bernegara (Arta, 2015:1; Syah, 2014:10). Tokoh pendidikan Indonesia Ki Hajar Dewantara mengungkapkan bahwa pendidikan adalah tuntunan di dalam hidup tumbuhnya anakanak, adapaun maksudnya, pendidikan adalah menuntut segala kekuatan kodrat yang ada pada anak-anak itu, agar mereka sebagai manusia dan sebagai anggota masyarakat dapat mencapai keselamatan dan kebahagiaan yang setinggi tingginya (Hasbullah, 2009:4).

Bagi sebagian orang, membaca novel mungkin hanya hiburan saja, namun tidak demikian. Jika kita membaca sebuah novel dengan cermat dan penghayatan kita akan menemukan pesan dan amanat yang ingin disampaikan oleh pengarang. Salah satu pesan dan amanat yang sering disampaikan pengarang dalam novelnya adalah nilai pendidikan. Nilai-nilai pendidikan dalam novel memberikan pelajaran bagi pembaca, bahkan memberikan kritikan, entah itu secara tersurat atau tersirat. Suyitno $(2014,107)$ menjelaskan bahwa sastra mampu membentuk kemampuan intelak dan watak manusia. Sastra pada awalnya mampu membentuk kompetensi dan karakter pribadi secara personal dan pada akhirnya dapat pula membentuk kompetensi dan karakter pribadi secara sosial. Sastra mampu berfungsi sebagai penyadar manusia sebagai sosok yang harus memiliki makna bagi kehidupan. Lebih jauh lagi dia juga menjelaskan bahwa sastra tidak hanya memasuki ruang dan seluk-beluk serta nilai-nilai kehidupan personal tetapi juga memasuki ruang dan seluk beluk serta nilai-nilai kehidupan manusia dalam arti kosmopolit-total. Satra dapat menelusup ke urat-urat nadi kehidupan politik, sejarah, perekonomian, perjuangan hak-hak asasi manusia, hukum dan aspirasi rakyat serta juga moral dan agama.

Nilai dapat diartikan sebagai sesuatu yang positif dan bermanfaat dalam kehidupan manusia dan harus dimiliki setiap manusia sebagai pandangan kehidupan. 
Mukhtar Latif mengartikan nilai sebagai sifat atau kualitas dari sesuatu yang bermanfaat bagi kehidupan manusi, baik lahir maupun batin.Bagi manusia nilai dijadikan landasan, alasan, atau motivasi dalam bersikap dan bertingkah laku (Latif. 2014: 232). Menurut Muhmidayelli, pada dasarnya nilai memiliki pengertian yang sangat luas, sehingga uraiannya selalu memiliki beragam makna. Nilai dapat diartikan dalam makna benar dan salah, baik dan buruk, manfaat atau berguna, indah dan jelek, dan lain sebagainya (Muhmidayelli, 2013:101).

Di samping itu ada kecendrungan alami di dalam diri manusia ke arah kebenaran dan wujud suci tertentu, yang juga bisa berkembang lebih jauh (Siswanto, 2015:87). Senada dengan pendapat tersebut, Latif (2014:232) mengungkapkan bahwa nilai diartikan sebagai sifat atau kualitas dari sesuatu yang bermanfaat bagi kehidupan manusia baik lahir maupun batin. Bagi manusia nilai dijadikan landasan, alasan, atau motivasi dalam bersikap dan bertingkah laku. Dari berbagai pengertian nilai yang dikemukakan oleh para ahli di atas, ada beberapa kesamaan yang mendasari pendangan para ahli tersebut mengenai pengertian nilai. Kesamaannya yaitu nilai merupakan sesuatu yang dipandang baik dan benar dan sesuatu yang dianggap buruk dan salah dalam kehidupan manusia. Nilai tidak hanya untuk memenuhi dorongan intelek dan keinginan manusia. Nilai berfungsi untuk membimbing dan membina manusia supaya menjadi lebih luhur, lebih matang sesuai dengan martabat humandignity. Oleh karena itu, nilai-nilai pendidikan sangat penting dan diharapkan berperan besar terhadap kemajuan kepribadian tingkahlaku seseorang (Soharab, 2016:2).

Pada konteks kajian akademik, studi nilai dibagi menjadi dua kelompok area, yaitu asketis dan etika. Dalam area asketis studi nilai diarahkan pada semacam upaya penelahaan dan pembenaran tentang keindahan dan kecantikan oleh manusia. Pada bidang etika lebih mengacu pada upaya penelahaan dan pembenaran tentang perilaku yang semestinya dilakukan oleh seseorang atau sekelompok orang. Singkat kata, studi nilai dalam konteks etika adalah penelahaan tentang persoalan moral dalam bentuk pemikiran reflektif tentang apa yang benar dan salah, baik dan tidak baik. Menurut Diane Tillman (Simbolon, 2018: 24) nilai pendidikan ada dua belas macam, yaitu, nilai kedamaian, nilai penghargaan, nilai cinta, nilai toleransi, nilai kejujuran, nilai kerendahan hati, nilai kerja sama, nilai kebahagiaan, nilai tanggung jawab, nilai kesederhanaan, nilai kebebasan, dan nilai persatuan.

Berdasarkan uraian di atas peneliti tertarik untuk mendiskripsikan nilai-nilai pendidikan dalam novel. Dipilihnya nilai-nilai pendidikan sebagai fokus penelitian karena nilai pendidikan dianggap sebagai sesuatu yang berguna bagi kehidupan manusia yang diperoleh melalui proses pengubahan sikap dan prilaku dalam upaya mendewasakan diri melalui beberapa upaya. Nilai pendidikan digunakan dalam upaya pembentukan pribadi manusia sebagai individu yang religius, sosial dan bermoral. Nilai pendidikan harus dihayati dan dipahami manusia, sebab nilai pendidikan mengarah kepada kebaikan dalam berpikir atau bertindak sehingga dapat mengembangkan budi pekerti dan pikiran. Selama manusia berusaha dalam meningkatkan kehidupannya, baik dalam meningkatkan dan mengembangkan kepribadiannya, selama itulah pendidikan masih terus berjalan. Untuk meneliti nilai-nilai pendidikan dalam novel, peneliti menggunakan Pandangan Diane Tillman tentang nilai-nilai pendidikan.

Salah satu novel yang dapat memberikan nilai-nilai pendidikan pada pembacanya ialah novel Ki Hadjar Sebuah Memoar karya Haidar Musyafa. Novel Ki Hadjar Sebuah Memoamempunyai keunggulan tersendiri, dimana penulis menceritakan kehidupan yang berisi tentang perjuangan dan kerja keras sehingga pembaca bisa merasakan masalah yang diangkat dalam cerita.

Dengan memadukan serta menceritakan aspek-aspek yang sering terjadi dalam kehidupan, novel Ki Hadjar Sebuah Memoarkarya Haidar Musyafa dianggap menjadi 
sebuah bentuk karya sastra yang menanamkan nilai-nilai pendidikan bagi para pembacanya. Berdasarkan konteks penelitian tersebut, penelitian ini bertujuan untuk mendeskripsikan nilai-nilai pendidikan yang terdapat pada novel Ki Hadjar Sebuah Memoar karya Haidar Musyafa dengan Perspektif Diane Tillman.

\section{METODE}

Penelitian ini menggunakan metode pendekatan deskriptif kualitatif dengan jenis penelitian kepusakaan. Penelitian kualitatif adalah penelitian yang bermaksud untuk memahami fenomena tentang apa yang dialami oleh subjek penelitian, seperti: perilaku, persepsi, motivasi, tindakan, dan lain sebagainya. Secara holistik, dan dengan cara deskripsi dalam bentuk kata-kata dan bahasa, pada suatu konteks khusus yang alamiah dan dengan memanfaatkan berbagai metode alamiah (Prastowo, 2012:23). Penelitian kepustakaan didukung oleh refrensi berupa teks novel dan buku penunjang dalam penelitian ini. Penelitian pustaka dilakukan oleh setiap peneliti dengan tujuan yang utama yaitu mencari dasar pijakan atau fondasi untuk memperoleh dan membangun landasan teori, kerangka berpikir dan menentukan dugan sementara atau sering pula disebut hipotesis penelitian, sehingga para peneliti dapat mengerti, melokasikan mengorganisasikan dan kemudian menggunakan variasi pustaka dalam bidangnya (Sukardi, 2003:33-34).

Sumber data yang digunakan dalam penelitian ini adalah sumber data tertulis atau kepustakaan berupa novel Ki Hadjar Sebuah Memoar karya Haidar Musyafa. Teknik pengumpulan data yang dilakukan dengan mempelajari buku-buku yang berkaitan dengan sastra dan nilai pendidikan, mengklarifikasi data yang termasuk kutipan nilainilai pendidikan, dan menganalisis data dari hasil temuan dalam penelitian. Dalam menganalisis data pada novel Ki Hadjar Sebuah Memoar karya Haidar Musyafa dilakukan dengan membaca, mengidentifikasi nilai-nilai pendidikan dalam novel $K i$ Hadjar Sebuah Memoar karya Haidar Musyafa, dan mendeskripsikan data nilai-nilai pendidikan dalam novel Ki Hadjar Sebuah Memoar karya Haidar Musyafa.

Dalam penelitian ini peneliti menggunakan ketekunan/keajegan pengamatan dalam pengecekan keabsahan data. Ketekunan/keajegan berarti mencari secara konsisten interpretasi dengan berbagai cara dalam kaitan dengan proses analisis yang konstan atau tentatif. Ketekunan pengamatan bermaksud menemukan ciri-ciri dan unsur-unsur dalam situasi yang sangat relevan dengan persoalan atau isu yang sedang dicari dan kemudian memusatkan diri pada hal-hal tersebut secara rinci. Hal ini berarti bahwa peneliti hendaknya mengadakan pengamatan dengan teliti dan rinci secara berkesinambungan terhadap faktor-faktor yang menonjol. Kemudian peneliti menalaah secara rinci pada sampai suatu titik sehingga pada pemeriksaan tahap awal tampak salah satu atau seluruh faktor yang ditelaah sudah dipahami. 


\section{HASIL DAN PEMBAHASAN \\ Nilai Pendidikan dalam Novel Ki Hadjar Sebuah Memoar karya Haidar Musyafa Perspektif Diane Tillman}

Berdasarkan rumusan masalah, hasil penelitian mencakup nilai-nilai pendidikan yang terdapay dalam novel Ki Hadjar Sebuah Memoar karya Haidar Musyafa perspektif Diane Tillman. Menurut Diane Tillman ada dua belas nilai-nilai pendidikan. Selanjutnya penulis akan menganalisis kedua belas nilai pendidikan itu di dalam novel Ki Hadjar Sebuah Memoar karya Haidar Musyafa seperti berikut ini.

\section{Nilai Kedamaian}

Kedamaian adalah keadaan yang tenang dan santai. Kedamaian berarti tidak sekadar tidak adanya perang. Kedamaian dunia tumbuh dari non-kekerasan, penerimaan, keadilan, dan komunikasi. Jika setiap orang di dunia ini merasadamai, dunia akan menjadi damai. Kedamaian adalah kediaman dari dalamyang mengandungkekuatan kebenaran. Kedamaian mengandung pikiran yang murni, perasaan yang murni, dan harapan yang murni. Kedamaian adalah karakter utama dari masyarakat yang beradab. Nilai kedamaian terlihat pada kutipan berikut.

"Jujur, meskipun aku keturunan seorang bangsawan, tapim aku tidak pernah mau diperlakukan secara istimewa. Aku lebih senang diperlakukan sebagai rakyat biasa, karena hal itu justru membuat hatiku lebih tenang dan lebih dekat dengan kalangan bawah (Musyafa, 2017: 388)."

Kutipan di atas mengambarkan nilai kedamaian. Nilai kedamaian ditunjukkan oleh Soewardi. Soewardi merasa lebih tenang jika dia diperlakukan sebagai rakyat biasa dari pada diperlakukan secara istimewa. Jadi kutipan tersebut mengandung nilai kedamaian.

\section{Nilai Penghargaan}

Setiap manusia berharga. Penghargaan seseorang adalah benih yang menumbuhkankepercayaan diri. Orang yang menghargai akan mendapat penghargaan. Saat ada kekuatan rendah hati dalam rasa hormat pada orang lain, kebijaksanaan berkembang serta kita menjadi adil dan mudah menyesuaikan diri terhadap sesame. Nilai penghargaan terlihat dalam kutipan berikut.

"Pada 29 Juni 1812, tepat pukul 5 sore dan bertempat di kedhaton Kasultanan Ngayogyokarto Hadiningrat, Gubernur Jendral Raffles menetapkan pangeran Notokusumo sebagai penguasa istana Puro Paku Alam I (Musyafa, 2017: 35)."

Kutipan di atas mengambarkan nilai penghargaan yang di tunjukkan oleh Gubernur Jendral Raffles. Gubernur Jendral Raffles memberi penghargaan kepada Pangeran Notokusumo dengan mengangkatnya sebagai raja istana Puro Paku Alam I karena jasa besarnya pada pemerintah Inggris. Nilai penghargaan juga terlihat pada kutipan berikut. 
"Kamu ini berbeda dengan anak-anak yang lainnya, Denmas Soewardi! Meskipun usimu jauh lebih muda di antara santri-santri lain, tapi kecerdasanmu jauh di atas mereka (Musyafa, 2017: 62)."

Kutipan di atas mengambarkan nilai penghargaan yang di tunjukkan oleh Kyai Haji Soleman. Kyai Haji Soleman memberikan menghargaan berupa pujian kepada Soewardi karena kecerdasan Soewardi yang jauh di atas anak-anak lainnya. Nilai penghargaan juga terlihat pada kutipan berikut.

"Sebagai orang tua, Ayah benar-benar bangga melihat kalian ikut bergabung dengan perkumpulan yang peduli dengan nasib wong cilik," kata ayah dengan raut wajah cerah (Musyafa, 2017:.151)."

Kutipan di atas mengambarkan nilai penghargaan yang di tunjukkan oleh Ayah Soewardi. Ayah Soewardi memberikan penghargaan berupa rasa kebangaan kepada Soewardi dan kakaknya karena dia mereka berdua ikut bergabung dengan organisasi yang peduli dengan nasib orang-orang kecil.

\section{Nilai Cinta}

Cinta bukanlah keinginan, gairah atau perasaan yang hebatpada seseorang atau objek. Tapi suatu kesadaran yang tidak egois dan mencintai dirinya. Cinta dapat diberikan pada Negara, pada menemukan tujuannya, pada kebenaran, keadilan, etika, masyarakat atau pada alam. Cinta berarti aku baik, memelihara, dan mengerti. Cinta adalah melihat keindahan pada setiap orang. Cinta yang tulus memberikan kebaikan, pemeliharaan, dan pengertian, melenyapkan kecemburuan dan menjaga tingkah laku. Nilai cinta terlihat seperti dalam kutipan berikut.

"Dengan penuh kasih sayang yang terhimpun, ibu Sadijah mengelus-elus kepalaku. Tak lama kemudian tubuh kecilku dipeluknya erat-erat (Musyafa, 2017: 48)."

Kutipan diatas menggambarkan nilai cinta yang ditunjukkan oleh ibu Sadijah. Ibu Sadijah mengelus-elus kepala soewardi anaknya yang sedang bersedih karena harus berpisah dengan keluarganya dengan penuh kasih sayang, kemudia dia memeluk tubuh soewardi erat-erat. Menggambarkan rasa cinta seorang ibu pada anaknya. Nilai cinta juga terlihat seperti dalam kutipan berikut.

"Senyum Kyai Haji Soleman semakin terkembang, sempurna. Sejurus kemudian dia mengelus-elus kepalaku dengan penuh kasih sayang (Musyafa, 2017: 60)."

Kutipan diatas menggambarkan nilai cinta yang ditunjukkan Kyai Haji Soleman. Kyai Haji Soleman mengelus-elus kepala Soewardi muridnya dengan penuh kasih sayang. Menggambarkan rasa cinta guru pada muridnya. Nilai cinta juga terlihat seperti dalam kutipan berikut. 
"Saat melihat aku menangis dengan air mata berlinang-linang, ibu langsung mendekap tunuhku erat-erat. Sehingga airmataku membasahi kebaya ibu yang berwarna putih. Semetara ayah dengan isak yang masih terdengan jelas berusaha mengelus-elus kepalaku dengan lembut. Hari itu aku benar-benar bahagia, karena kembali merasakan kehangatan kasih sayang kedua orang tua (Musyafa, 2017: 149)."

Kutipan diatas menggambarkan nilai cinta yang ditunjukkan oleh ibu dan ayah Soewardi. Ibu Soewardi memeluk tubbuh anaknya yang sedang menangis dengan erat, sementara ayah Soewardi mengelus kepala Soewardi dengan lembut. Keluarga ini kembali berkumpul setlah lama berpisah dengan Soewardi yang menuntut ilmu agama di pesantren. Menggambarkan nilai cinta orang tua pada anaknya.

\section{Nilai Toleransi}

Toleransi adalah terbuka dan reseptif pada indahnya perbedaan. Toleransimenghargai individu dan perbedaannya, menghapus topeng dan ketegangan yang disebabkan oleh ketidakpedulian. Menyediakan kesempatan untukmenemukan dan menghapus stigma yang disebabkan oleh kebangsaan, agama, dan apa yang diwariskan. Toleransi adalah saling menghargai melalui saling pengertian. Benih dari toleransi adalah cinta, disiram dengan kasih, dan pemeliharaan. Yang tahu menghargai kebaikan dalam diri orang lain dan situasi, memiliki toleransi. Melalui pengertian dan keterbukaan pikiran, orang yang toleran memperlakukan orang lain secara berbeda, menerimanya, menyesuaikan diri, dan menunjukkan toleransinya. Akhirnya, hubungannya berkembang. Nilai toleransi terlihat pada kutipan berikut.

"Sejak kecil aku hidup di lingkungan puri, sehingga memungkinka aku untuk bergaul dengan teman-teman di lingkungan istana Kadipaten Puro Pakualaman maupun dari kalangan yang dari rakyat biasa (Musyafa, 2017: 42)."

Kutipan di atas menggambarkan nilai toleransi yang ditunjukkan oleh Soewardi. Meski merupakan keturunan priai namun Soewardi tidak pernah memandang strata sosial dalam bergaul. Jadi, kutipan data tersebut menggambarkan nilai toleransi. Nilai toleransi juga terlihat seperti dalam kutipan berikut.

"'Sudahlah, Man! Tak perlu kamu berkata seperti itu,' jawab Kangmas Soerjopranoto dengan ramah. 'apa yang dikatakan oleh Soewardi itu benar, jika kita ini sama-sama rakyat. Sama-sama kawulu di Kadipaten Pakualaman ini (Musyafa, 2017: 43).'”

Kutipan di atas menggambarkan nilai toleransi. Nilai toleransi ditunjukkan oleh Soerjopranoto, Soerjopranoto memiliki rasa toleransi, menurutnya dia dan Sariman sama-sama rakyat dan kawulu di Kadipaten Pakualaman, tidak ada kau bangsawan dan kaum biasa semuanya sama. Jadi, kutipan data tersebut menggambarkan nilai toleransi. Nilai toleransi juga terlihat seperti dalam kutipan berikut. 
"Seperti anak-anak yang lainnya, setelah pelajaran di sekolah selesai, maka aku sering pergi bermain dengan teman-temanku yang mayoritas berasal dari kalangan rakyat biasa (Musyafa, 2017: 73)."

Kutipan diatas menggambarkan nilai toleransi yang ditunjukkan oleh Soewardi. Sepulang dari sekolah Soewardi sering bermain dengan teman-temannya yang dari kalangan rakyat biasa. Tanpa mempermasalahkan latar belakang teman-temannya. Jadi, kutipan data tersebut menggambarkan nilai toleransi.

\section{Nilai Kejujuran}

Kejujuran adalah mengatakan kebenaran. Kejujuran berarti tidak kontradiksidalam pikiran, kata atau tindakan. Pikiran, kata-kata, tindakan yang jujur menciptakan harmoni. Kejujuran adalah kesadaran akan apa yang benar dan sesuai dengan perannya, tindakannya, dan hubungannya. Dengan kejujuran, tidak ada kemunafikan atau kepalsuan yang menciptakan kebingungan dan ketidakpercayaan dalam pikiran dan hidup orang lain. Nilai kejujuran terlihat pada kutipan berikut.

"Saat itu aku belum mengatakan kepada ayah dan ibu jika aku tidak naik kelas. Oleh karena itu, aku ingin mengatakan kepada kedua orang tuaku tentang kejadian yang sesungguhnya. Aku tidak ingin menyembunyikan kenyataan itu terlalu lama, karena hal itu justru akan membuat kedua orangtuaku semakin sakit dan kecewa (Musyafa, 2017:173)."

Kutipan di atas menggambarkan nilai kejujuran. Nilai kejujuran ditunjukkan oleh Soewardi. Soewardi ingin mengatakan yang sebenarnya kepada orangtuanya bahwa dia tidak naik kelas. Kutipan tersebut menggambarkan nilai kejujuran. Nilai kejujuran juga terlihat pada kutipan berikut.

"Pada keesokan harinya, dengan perasaan takut, aku menemui kedua orangtuaku dan mengatakan bahwa aku tidak naik kelas. Saat itu aku sudah benar-benar pasrah dengan keadaanku. Aku juga sudah siap menerima caci maki dari Ayah dan Ibu, jika apa yang aku katakan itu membuat mereka kecewa atau marah (Musyafa, 2017:173)."

Kutipan di atas menggambarkan nilai kejujuran yang ditunjukkan oleh Soewardi. Meski merasa takut Soewardi mengatakan yang sebenarnya kepada Ayah dan Ibunya bahwa dia tidak naik kelas. Kutipan tersebut menggambarkan nilai kejujuran. Nilai kejujuran juga terlihat pada kutipan berikut.

“Jujur, meskipun aku keturunan seorang bangsawan, tapim aku tidak pernah mau diperlakukan secara istimewa. Aku lebih senang diperlakukan sebagai rakyat biasa, karena hal itu justru membuat hatiku lebih tenang dan lebih dekat dengan kalangan bawah (Musyafa, 2017: 388)."

Kutipan di atas menggambarkan nilai kejujuran. Nilai kejujuran ditunjukkan oleh Soewardi. Soewardi mengatakan kebenaran bahwa dia tidak suka dilakukan secara 
istimewa. Dia lebih suka diperlakukan seperti rakyat biasa. Kutipan tersebut mengandung nilai kejujura.

\section{Nilai Kerendahan Hati}

Kerendahan hati melenyapkan kesombongan. Kerendahan hati menjadikan ringan dalam menghadapi tantangan. Rendah hati sebagai nilai tertinggi mengizinkan diri dan kemuliaanya bekerja untuk dunia yang lebih baik. Pribadi yang rendah hati mendengarkan dan menerima orang lain. Rendah hati adalah tetap teguh dan mempertahankan kekuatan diri serta tidak berkeinginan untuk mengatur yang lainnya. Rendah hati mengurangi perasaan posesif yang membangun dinding kesombongan. Rendah hati menciptakan pikiran yang terbuka dan pengakuan atas kekuatan diri dan orang lain. Kesombongan merusak atau menghancurkan nilai unik setiap pribadi, dan pelanggaran atas hak pribadi. Nilai kerendahan hati terlihat pada kutipan berikut.

"Tapi aku tidak merasa seperti itu, Kyai. Sebab aku merasa belum banyak memahami kandungan ayat-ayat Al-Qur'an, apalagi menghafalnya,' kataku dengan suara datar (Musyafa, 2017: 62)."

Kutipan di atas menggambarkan nilai kerendahan hati. Kerendahan hati ditunjukkan oleh Soewardi, dia tidak sombong saat dipuji cerdas oleh gurnya dan merendahkan diri dengan menyatakan bahwa dia belum banyak memahami kandungan ayat-ayat Al-Qur'an. Jadi kutipan tersebut menggambarkan nilai kerendahan hati. Nilai kerendahan hati juga tergambar pada kutipan berikut.

"aku mengangguk-angguk mendengar jawaban teman yang baru aku kenal itu. "Wah, panggil aku Soewardi saja. Tidak perlu memanggilku dengan sebutan Raden Mas. Lha wong aku ini hanya anak rakyat biasa, kok!' kataku dengan suara datar (Musyafa, 2017: 111)."

Kutipan di atas menggambarkan nilai kerendahan hati. Nilai kerendahan hati ditunjukkan oleh Soewardi. Meski dia merupakan keturunan kerajaan dia tidak mau dipanggil dengan sebuatan Raden Mas dan dengan kerendahan hati dia mengatakan dia hanya anak rakyat biasa. Jadi kutipan tersebut mengandung nilai kerendahan hati. Nilai kerendahan hati juga terlihat pada kutipan berikut

"Soetomo hanya tersenyum mendengar perkataan Tjipto Mangoenkoesoemo. Aku memandang wajah Soetomo. Dia tersenyum kemusian berkata. 'Jangan dengarkan perkataan Tjipto, Denmas! Aku ini hanya siswa biasa seperti yang lainnya (Musyafa, 2017: 113).

Kutipan di atas menggambarkan nilai kerendahan hati yang ditunjukkan oleh Soetomo. Soetomo mengatakan kepada Soewardi jangan mendengarkan perkataan Tjipto Mangoenkoesoemo. Dia merendahkan diri dan mengatakan bahwa dia hanya siswa biasa sama seperti siswa lainnya. Jadi, kutipan tersebut mengandung nilai kerendahan hati. 


\section{Nilai Kerja Sama}

Kerja sama terjadi saat orang bekerja bersama mencapai tujuan bersama.Orang yang bekerja sama menciptakan kehendak baik dan perasaan murni pada sesama dan tugas yang dihadapi. Saat bekerja sama, ada kebutuhan untuk mengetahui apa yang dibutuhkan. Kadang kita membutuhkan sebuah ide, kadang perlu untuk membuang ide kita. Kadang kita perlu memimpin, dan kadang kita perlu mengikuti. Nilai kerja sama terlihat pada kutipan berikut.

"Kangmas Soejopranoto manggut-manggut mendengar perkataanku. Sejuruh kemudian dia berkata, 'itulah sebabnya aku ingin mengajakmu untuk mengenal lebih dekat lagi tentang perkumpulan Sarekat Islam, Dimas! Kita cari tahu samasama, sebenarnya seperi apa arah perjuangan perkumpulan yang memiliki anggota ribuan itu (Musyafa, 2017: 200)."

Pada kutipan di atas menggambarkan nilai kerja sama yang ditunjukkan oleh Soejopranoto dan Soewardi. Mereka berdua bekerja sama untuk mencari tahu tentang arah perjuangan perkumpulan Sarekat Islam. Mereka bekerja sama untuk mencapai tujuan bersama mengetahui tentang Sarekat Islam. Nilai kerja sama juga terlihat pada kutipan berikut.

"Semakin lama hubunganku dengan Tjipto Mangoenjoesoemo dan Douwes Dekker semakin lekat. Lebih dari itu, sunggu, dalam hal-hal yang ada kaitannya dengan masalah pekerjaanpun kami bertiga selalu bekerja bahu membahu untuk mewujudkan cita-cita perjuangan. Hal itulah yang kemudian membuat orang-orang sering memanggil kami bertiga dengan sebutan Janget Kinatelon atau tiga serangkai (Musyafa, 2017: 210)."

Kutipan di atas menggambarkan nilai kerja sama. Nilai kerja sama ditunjukkan oleh Soewardi, Tjipto Mangoenjoesoemo dan Douwes Dekker. Mereka bertiga selalu bekerja sama dan bahu membahu dalam pekerjaan untuk mewujudkan cita-cita perjuangan. Mereka bekerja sama untuk mencapai tujuan bersama yaitu mewujudkan cita-cita perjuangan.Nilai kerja sama juga terlihat pada kutipan berikut.

"Dengan tetap menjalin kerja sama yang baik dengan kaum nasionalis dan berbagai organisasi itu membuat kami selalu mendapat kabar terkini tentang perkembangan yang terjadi di seantero Nusantara (Musyafa, 2017: 323)."

Kutipan di atas menggambarkan nilai kerja sama. Nilai kerja sama ditunjukkan oleh soewardi dan kaum nasionalis. Soewardi bekerja sama dengan kaum nasionalis untuk selalu mendapatkan kabar tentang perkembangan yang terjadi di seantero Nusantara. Kersa sama dilakukan oleh Soewardi untuk menciptakan kehendak baik yaitu mengetahui kabar tentang Nusantara.

\section{Nilai Kebahagiaan}

Di mana cinta dan damai ada dalam hati, kebahagiaan tumbuh secara otomatis. Kebahagiaan tidak dapat dibeli, dijual atau ditawar. Kebahagiaan didapat melalui murni 
dan tidak egoisnya sikap serta tindakan. Kebahagiaan sejati adalah merasa puas di dalamnya. Memiliki harapan baik untuk semua orang, memberi kebahagiaan dalam hati. Kebahagiaan adalah keadaan damai di mana tidak ada kekerasan. Nilai kebahagiaan terlihat pada kutipan berikut.

"Dari hasil pembicaraan itu tahulah aku jika Kiyai Haji Soeleman bersedia menerimaku sebagai santrinya. Tentu saja hal itu membuat Ayah dan Ibu merasa lega, bahagia (Musyafa, 2017: 58)."

Kutipan di atas menunjukkan nilai kebahagiaan yang ditunjukkan Ayah dan Ibu Soewardi. Mereka bahagia karena Kiyai Haji Soelemanmau meneriman Soewardi sebagai santrinya. Nilai kebahagiaan juga terlihat pada kutipan berikut:

"Saat itu aku benar-benar merasa bahagia, karena impian dan cita-citaku untuk sekolah sebentar lagi akan menjadi kenyataan (Musyafa, 2017: 67)."

Kutipan di atas menggambarkan nilai kebahagiaan yang ditunjukkan oleh Soewardi. Soewardi merasa sangat bahaia karena cita-cita sejak kecil untuk bersekolah sebentar lagi akan menjadi kenyataan. Nilai kebahagiaan terlihat pada kutipan berikut.

"Aku benar-benar bahagia mendengar perkataan Sariman. Meskipun dia berasal dari kalangan jelata, tapi dia memiliki impian dan cita-cita sangat tinggi. Aku jadi membayangkan, jika anak-anak jelata seperti Sariman dan teman-temannya bisa sekolah, maka masa depan bangsaku akan cerah (Musyafa, 2017:75)."

Kutipan di atas menunjukkan nilai kebahagiaan yang ditunjukkan oleh Soewardi. Soewardi merasa bahagia mendengarkan perkataan temannya Sariman yang memilik impian dan cita-cita tinggi meskipun dia berasal dari kalangan jelata. Soewardi membayangkan jika rakyat jelata bisa sekolah maka masa depan bangnya akan cerah.

\section{Nilai Tanggung Jawab}

Bertanggung jawab adalah melakukan tugasmu. Bertangung jawab adalah menerima kebutuhanmu dan melakukan tugasmu dengan sebaik-baiknya. Bertangung jawab berarti melakukan kewajibanmu dengan sepenuh hati. Tanggung jawab bukan hanya suatu kewajiban, tetapi juga sesuatu yang membantu kita mencapai tujuan. Tangung jawab adalah menggunakan seluruh daya untuk perubahan yang positif. Nilai tanggung jawab terliha pada kutipan berikut.

"Meskipun kondisi bayi itu sangat lemah dan jauh dari harapan, tapi Ayah tetap menganggap bayi laki-laki itu sebagai nikmat dan amanah dari Allah, sehingga Ayah memiliki kewajiban untuk menjaga dan merawatnya (Musyafa, 2017: 39)."

Kutipan di atas menggambarkan nilai tanggung jawab yang ditunjukkan oleh Ayah Soewardi. Ayah Soewardi menerima apapun kondisi bayinya dengan penuh rasa syukur. Dia menganggap bayinya sebagai naikmat dan amanat dari Allah sehingga dia 
memiliki tanggung jawab untuk menjaga dan merawatnya. Nilai tanggung jawab jura terlihat pada kutipan berikut.

"Sejak menduduki jabatan sebagai propaganda di perkumpulan Boedi Oetomo, maka setiap selesai mengikuti pelajaran di STOVIA, aku langsung terlibat aktif bersama dengan pengurus Boedi Oetomo yang lain untuk membahas berbagai macam agenda yang ingin dijalankan (Musyafa, 2017: 157)."

Pada kutipan di atas terlihat nilai tanggung jawab. Nilai tanggung jawab ditunjukkan oleh Soewardi. Setiap selesai mengikuti pelajaran Soewardi menjalankan tanggung jawabnya sebagai propoganda di perkumpulan Boedi Oetomo dengan langsung terlibat aktif dengan pengurus yang lain untuk membahas berbagai agenda yang ingin dijalankan. Jadi kutipan tersebut menggambarkan nilai tanggung jawab. Nilai tangggung jawab juga terlihat pada kutipan berikut.

"Sebagai salah seorang propaganda organisasi, maka Hoofd Bestuur Boedi Oetomo memberikan tugas kepadaku untuk memperluas jangkauan organisasi dengan cara melakukan korespondensi dengan beberapa instansi pemerintah dan mendorong mereka bersedia membantu perjuangan Boedi Oetomo. Sebagai bawahan, tentu saja aku melaksanakan semua tugas itu dengan sebaik-baiknya (Musyafa, 2017: 160)."

Pada kutipan diatas terlihat nilai tanggung jawab yang ditunjukkan oleh Soewardi. Sebagai bawahan Soewardi menjalankan tanggung jawabnya dengan melakukan korespondensi dengan instansi pemerintah dan mendorong mereka untuk bersedia membantu perjuangab Boedi Oetomo.

\section{Nilai Kesederhanaan}

Kesederhanaan adalah berada di saat ini dan tidak membuat masalah menjadi rumit. Kesederhanaan adalah memberikan kesabaran, persahabatan, dan dorongan semangat. Kesederhanaan mengajarkan kita untuk hidup ekonomis, bagaimana menggunakan sumber alam dengan bijaksana, memikirkan kepentingan generasi yang akan dating. Nilai kesederhanaan terlihat pada kutipan berikut.

"Saat aku sedang meratapi kegagalanku, Tjipto Mangoenkoesoemo, Douwes Dekker, Raden Mas Tirtodirjo, dan beberapa orang teman lainnya justru memberikan semangat padaku bahwa apa yang sedang aku alami itu bukan sebuah kegagalan. Tapi hanya sebuah proses kecil yang harus aku lalui untuk menuju pada puncak prestasi yang gemilang (Musyafa, 2017: 171)."

Pada kutipan di atas mengandung nilai kederhanaan hati yang ditunjukkan oleh Tjipto Mangoenkoesoemo, Douwes Dekker, Raden Mas Tirtodirjo, dan beberapa orang teman Soewardi. Mereka memberikan dorongan semangat kepada Soewardi untuk tidak menyerah karena kegagalan yang dia alami. Menurut mereka kegagalan hanya proses kecil yang harus dilalui untuk menuju kesuksesan. Kutipan tersebut 
mengandung nilai kesederhanaan. Nilai kerendahan hati juga terlihat pada kutipan berikut.

"Begitu juga dengan Tjipto Mangoenkoesoemo. Tak kurang-kurangnya dia memberikan motivasi kepadaku agar bangkit dari keterpurukan. Agar aku kembali meneruskan perjuangan dalam mewujudkan impian dan cita-citaku, meski jalannya berbeda (Musyafa, 2017:171)."

Kutipan di atas mengandung nilai kerendahan hati. Kerendahan hati ditunjukkan oleh Tjipto Mangoenkoesoemo. Dia memberikan motivasi kepada Soewardi untuk bangkit dari keterpurukan dan kembali berjuang untuk mewujudkan cita-citanya. Kutipan tersebut mengandung nilai kerendahan hati. Nilai kesederhanaan juga terlihat pada kutipan berikut.

"Saat itu Ayah juga mengatakan akan mengusahakan, jika sekiranya aku ingin mengulang sekolah sampai lulus di STOVIA. Tapi aku menolaknya dengan halus. Sebab aku tahu jika kondisi ekonomi keluargaku sedang kekurangan saat iru (Musyafa, 2017:174)."

Kutipan di atas menunjukkan nilai kesederhanaan yang ditunjukkan oleh Soewardi. Soewardi menolak keinginan ayahnya untuk mengusahakan biaya sekolahnya di STOVIA, namun Soewardi menolak karena dia tau kondisi ekonomi keluarganya saat itu sedang kekurangan. Jadi pada kutipan tersebut menggambarkan nilai kesederhaan.

\section{Nilai Kebebasan}

Orang menginginkan kebebasan untuk mencapai hidup yang bermanfaat, untuk memilih secara bebas gaya hidup yang sesuai dengan dirinya, dan anak-anaknya dapat tumbuh secara sehat, dan dapat berkembang melalui hasil karyanya, melalui tangan, kepala, dan hati mereka. Kebebasan dapat disalahartikan menjadi payung yang luas dan tak terhingga, yang memberikan izin untuk melakukan apa yang aku sukai, kapan dan kepada siapa pun yang aku mau. Konsep tersebut menyalahi dan menggunakan secara salah arti kebebasan. Kebebasan diri adalah bebas dari kebimbangan dan kerumitandalam pikiran, intelek dan hati, yang timbul dari negatifitas. Nilai kebebasan terlihat pada kutipan berikut.

"Meskipun sejak kecil kedua orang tuaku sudah membiasakan aku dengan pendidikan agama dan pelajaran kesenian Jawa, tapi kedua orangtuaku tidak pernah mengekang aku dan saudara-saudaraku, sehingga kami dapat bebas melakukan apa saja yang membuat hati kami merasa senang (Musyafa, 2017: 46)."

Pada kutipan di atas terlihat nilai kebebasan. Nilai kebebasan ditunjukkan oleh Soewardi. Soewardi bebas melakukan apa saja yang membuat hatinya senang karena Ayahnya tidak pernah mengekang. Soewardi juga bebas berteman dengan siapa saja 
termasuk dengan kalangan rakyat biasa. Kutipan tersebut menggambarkan nilai kebebasan.

\section{Nilai Persatuan}

Persatuan adalah keharmonisan dengan dan antara individu dalam satu kelompok. Persatuan dibangun dari saling berbagi pandangan, harapan, dantujuan mulia atau demi kebaikan semua. Persatuan membuat tantangan beratmenjadi mudah. Persatuan menciptakan pengalaman bekerja sama, meningkatkan antusiasme dalam menghadapi tantangan dan menciptakan suasana yang menguatkan. Persatuan menciptakan rasa memiliki dan meningkatkan kebaikan untuk semua (Simbolon, 2018:24). Nilai persatuan terlihat pada kutipan berikut.

"Pada saat Hoofd Inspektuur mengeluarkan pernyataan ingin mengeluarkan Soetomo dari STOVIA secara serentak pelajar-pelajar yang ikut bergabung dengan pekumpulan Boedi Oetomo menyatakan siap mengundurkan diri dari STOVIA, jika Soetomo benar-benar akan dikeluarkan (Musyafa, 2017: 159)."

Kutipan diatas menggambarkan nilai persatuan. Nilai persatuan ditunjukkan oleh pelajar STOVIA yang menjadi anggota organisasi Boedi Oetomo. Para pelajar tersebut siap mengundurkan diri dari STOVIA apabila Soetomo dikeluarkan dari ATOVIA. Tindakan pelajar tersebut membuat Hoofd Inspektuur membatalkan niatnya untuk mengeluarkan Soetomo dari STOVIA. Apa yang dilakukan oleh pelajar tersebut untuk kebaikan bersama. Nilai persatuan juga terlihat pada kutipan berikut.

"Setelah merundingkan masalah itu dengan Tjipto Mangoenkoesoemo dan Douwes Dekker melalui surat, akhirnya kami bertiga sepakat memilih Negeri Belanda sebagai tempat pembauangan. Alasan kami memilih Negeri Belanda sebagai tempat pembuanagan tak lain karena kami ingin menyerap banyak ilmu di negara yang saatb itu menjadi kiblat pengetahuan bagi para pelajar Boemi Poetra (Musyafa, 2017: 246)."

Kutipan di atas menggambarkan nilai persatuan yang ditunjukkan oleh SoewardiTjipto Mangoenkoesoemo dan Douwes Dekker. Mereka sepakat untuk memilih Negeri Belanda sebagai tempat pembuangan mereka oleh pemerintah Belanda. Mereka memilih Belanda sebagai tempat pembuanagan karena ingin menyerap banyak ilmu di negara yang saat itu menjadi kiblat pengetahuan bagi para pelajar Boemi Poetra. Nilai persatuan juga terlihat pada kutipan berikut.

"Kabar jika kami bertiga hendak menjalani masa pembuangan di Negeri Belanda, maka hal itu langsung mengundang simpati dari ketiga organisasi pergerakan yanag ada pada saat itu. Secara bersama-sama, Serekat Islam, Muhammadiyah dan Boedi Oetomo melakukan penggalangan dana besar-besaran dengan tujuan agar kami bertiga dapat berangkat Ke Negeri Belanda dengan membawa serta keluarga masing-masing (Musyafa, 2017:242)." 
Kutipan di atas menggambarkan nilai persatuan yang ditunjukkan oleh organisasi Serekat Islam, Muhammadiyah dan Boedi Oetomo. Mengetahui akan dibuangnya Soewardi, Thipto Mangoenkoesoemo dan Douwes Dekker ke Belanda maka organisasi-organisasi tersebut melakukan penggalangan dana besar-besaran agar Soewardi, Thipto Mangoenkoesoemo dan Douwes Dekker dapat membawa keluarganya masing-masing ke Belanda. Apa yang dilakukan Serekat Islam, Muhammadiyah dan Boedi Oetomo adalah untuk kebaikan bersama sebagai pejuang kemerdekaan.

\section{SIMPULAN}

Berdasarkan penelitian yang telah dilakukan oleh peneliti pada novel Ki Hadjar Sebuah Memoar karya Haidar Musyafa, dapat disimpulkan bahwa dalam novel tersebut mengandung nilai-nilai pendidikan perspektif Diane Tillman. Dari penelitian ini ditemukan dua belas nilai pendidikan dalam novel Ki Hadjar Sebuah Memoar karya Haidar Musyafa. Dengan rincian data: nilai kedamaian, nilai penghargaan, nilai cinta, nilai toleransi, nilai kejujuran, nilai kerendahan hati, nilai kerjasama, nilai kebahagiaan, nilai tanggung jawab, nilai kesederhaan, nilai kebebasan dan nilai persatuan.

\section{DAFTAR RUJUKAN}

Hasbullah. (2009). Dasar-dasar Ilmu Pendidikan. Jakarta: PT Raja Grafindo Persada. Latif, Mukhtar. (2014). Filsafat IImu. Jakarta: Prenadamedia Group.

Luxemburg, Jan Van, dkk. (1986). Pengantar Ilmu Sastra. Jakarta: Gramedia. Muhmidayelli. (2013). Filsafat pendidikan. Bandung: Refrika Aditama.

Musyafa, Haidar. (2017). Ki Hadjar Sebuah Memoar. Tangerang Selatan: Imania. Prastowo, Andi. (2012). Metode Penelitian Kualitatif dalam Prespektif Rancangan Penelitian. Jogjakarta: Ar-Ruzz Media.

Qomar, Mujamil. (2012). Kesadaran Pendidikan Sebuah Penentuan Keberhasilan Pendidikan. Jogjakarta: Ar-Ruzz Media.

Sedana Arta, Ketut. (2015). Sejarah Pendidikan. Yogyakarta: Media Akademi.

Simbolon, Lamganda H. (2018). "Nilai-Nilai Pendidikan Dalam Novel KEMAYORAN KARYA NH. DINI: ANALISIS SOSIOLOGI SASTRA", (Skripsi, Universitas Sumatera Utara, Medan).

Siswanto. (2015). Filsafat dan Pemikiran Pendidikan Islam. Surabaya: Pena Salsabila. Siswantoro. (2016). Metode Penelitian Sastra. Yogyakarta: Pustaka Pelajar.

Soharab, Vivi Zulfianti. (2017). "Nilai-nilai Pendidikan dalam Novel Sabtu Bersama Bapak Karya Adhitya Mulya." Jurnal Bastra, 3(3).

Sukardi. (2003).Metode Penelitian Pendidikan. Jakarta: PT. Bumi Kasara.

Suyitno. (2014). Kajian Novel dalam Spektroskop Feminisme dan Nilai Pendidikan. Yogyakarta: Garaha IImu.

Syah, Muhibbin. (2014). Psikoklogi Pendidikan dengan Pendekatan Baru. Bandung: PT Remaja Rosda Karya.

Wellek, Rene dan Austin Warren. (2016). Teori Kesusastraan. Jakarta: Gramedia. 